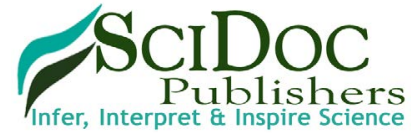

International Journal of Food Science, Nutrition and Dietetics (IJFS)

ISSN:2326-3350

\title{
Synbiotic Fruit Yoghurt with Enhanced Functionality
}

Editorial

S Sarkar

Deputy General Manager (Quality Assurance), Metro Dairy Limited, Barrackpore-Barasat Link Road, Subashnagar, P.O. Neelgunj Bazar, Kolkata, West Bengal, India.

Recent societal interest in healthful foods has led to the development of functional dairy products that basically provide health benefits in addition to their fundamental nutrients. Amongst diverse fermented milk products, yoghurt is most popular due to its functional attributes $[1,9]$ coupled with its general positive image among consumers. Yoghurt is considered as the most suitable probiotic carrier and inclusion of probiotic cultures in yoghurt is suggested to extend the functional properties of normal yoghurt [22]. Further, dietetic value of yoghurt can be enriched with the inclusion of fruits or prebiotic $[8,20]$.

Fruit juices may be a better carrier than milk for probiotic [24] and fermented milks incorporated with fruit matrices may be an alternative dairy product to deliver probiotic bacteria [4]. It has been reported that yogurt containing fruit could provide probiotics, prebiotics, high-quality protein, important fatty acids and a mixture of vitamins and minerals that have the potential to exert synergistic health effects. Beneficial synergistic relation between fruit and probiotic bacteria suggest their incorporation in yoghurt resulting in new era in functional food innovations [23].

Honey is basically a supersaturated solution of fructose and glucose [14] and contains minor components such as phenolic acids and flavonoids, enzymes glucose oxidase and catalase, ascorbic acid, carotenoids, organic acids, amino acids, proteins and $\alpha$-tocopherol [11]. Honey exhibits both bacteriostatic and bactericidal effects against gram-positive bacteria [6] and the antibacterial activity is attributed to both peroxide and non peroxide substances. Honey can be safely used as an alternative treatment for clinical conditions such as cardiovascular diseases, chemo-preventive activity in multistage carcinogenesis, improving endothelial function and plasma lipid profile [2], antimutagenic, antiproliferative, hepatoprotective, hypoglycemic, antioxidant [10, 13] human pathogen control, antiviral activity [16], treatment of wounds or stomach ulcers [12].

Honey may contain more than twenty oligosaccharides [25] and its spectrum varies with the type of honey [19]. Oligosaccharides such as isomaltose, melezitose [26] and raffinose [18], present in honey have been reported to be responsible for growth stimulating of bifidobacteria [15]. Oligosaccharides from honey can be utilized to yield beneficial metabolites that promote the prebiotic effect by selectively modulating the gut microbial balance in $\mathrm{fa}$ vour of probiotic lactobacilli and bifidobacteria, thus improving the host metabolic function [17]. Research revealed highest stimulatory effect of honey for both Lactobacillus delbrueckii subsp. bulgaricus $\left(230 \times 10^{6} \mathrm{cfu} / \mathrm{g}\right)$ and Streptococcus thermophilus (395 × $10^{6}$ cfu/g) [21]. Further, viable populations of probiotics such as Lactobacillus acidophilus [5] and Bifidobacteria encountered in bioyoghurt containing honey was within the range required for exhibiting health effects [3]. Retention of viability of probiotic bacteria such as Lactobacillus acidophilus LA-5 and Bifidobacterium BB-12 in bioyogurt containing honey at a level of $10^{7} \mathrm{cfu} / \mathrm{g}$ upto 35 days of storage at $2-4^{\circ} \mathrm{C}$ was noted [7].

Conjugated application of probiotics, honey and fruits are recommended for the manufacture of synbiotic fruit yoghurt with enhanced functional attributes.

\section{References}

[1]. Allgeyer LC, Miller MJ, Lee SY. Sensory and microbiological quality of yogurt drinks with prebiotics and probiotics. J Dairy Sci. 2010 Oct;93(10):4471-9. doi: 10.3168/jds.2009-2582. PubMed PMID: 20854980.

[2]. M Alvarez-Suarez J, Giampieri F, Battino M. Honey as a source of dietary antioxidants: structures, bioavailability and evidence of protective effects against human chronic diseases. Curr Med Chem. 2013;20(5):621-38. PubMed PMID: 23298140.

[3]. Bakr I, Mohamed T, Tammam A, El-Gazzar F. Characteristics of bioyoghurt fortified with fennel honey. Int J Curr Microbiol Appl Sci. 2015;4(3):95970.

[4]. Barat A, Ozcan T. Growth of probiotic bacteria and characteristics of fermented milk containing fruit matrices. Int J Dairy Technol. 2017 Mar 27;70: 120-29.

[5]. Bhardwaj A, Puniya M, Sangu KP, Kumar S, Dhewa T. Effect of Prebiotics on Growth of the Selected Lactobacilli Culture Isolated from Dairy Products. J Dairy Sci Technol. 2013 May 21;2(2):1-8.

[6]. Bogdanov $S$. Nature and origin of the antibacterial substances in honey. Lebensm Wiss Technol. 1997 Nov 1;30(7):748-53.

[7]. Caldeira LA, Alves ÉE, Ribeiro AD, Rocha Júnior VR, Antunes AB, Reis AF, et al. Viability of probiotic bacteria in bioyogurt with the addition of honey from Jataí and Africanized bees. Pesq Agropec Bras. 2018 Feb;53(2):206-11.

\section{*Corresponding Author:}

S Sarkar,

Deputy General Manager (Quality Assurance), Metro Dairy Limited, Barrackpore-Barasat Link Road, Subashnagar, P.O. Neelgunj Bazar, Kolkata-700121, West Bengal, India. E-mail: drsurajitsarkar@yahoo.co.in

Received: January 30, 2019

Published: January 31, 2019

Citation: S Sarkar. Synbiotic Fruit Yoghurt with Enhanced Functionality. Int J Food Sci Nutr Diet. 2019;8(1e):1-2. doi: http://dx.doi.org/10.19070/2326-3350-190008e

Copyright: S Sarkar ${ }^{\circ}$ 2019. This is an open-access article distributed under the terms of the Creative Commons Attribution License, which permits unrestricted use, distribution and reproduction in any medium, provided the original author and source are credited. 
[8]. Cruz AG, Cavalcanti RN, Guerreiro LM, Sant'Ana AS, Nogueira LC, Oliveira CA, et al. Developing a prebiotic yogurt: rheological, physico-chemical and microbiological aspects and adequacy of survival analysis methodology. J Fd Engineer. 2013 Feb 1;114(3):323-30

[9]. El-Abbadi NH, Dao MC, Meydani SN. Yogurt: role in healthy and active aging-. Am J Clin Nutr. 2014 May;99(5 Suppl):1263S-70S. doi: 10.3945/ ajcn.113.073957. PubMed PMID: 24695886.

[10]. Erejuwa OO, Gurtu S, Sulaiman SA, Wahab MS, Sirajudeen KN, Salleh MS. Hypoglycemic and antioxidant effects of honey supplementation in streptozotocin-induced diabetic rats. Int J Vitam Nutr Res. 2010 Jan;80(1):74-82. doi: 10.1024/0300-9831/a000008. PubMed PMID: 20533247.

[11]. Ferreres F, García-Viguera C, Tomás-Lorente F, Tomás-Barberán FA. Hesperetin: A marker of the floral origin of citrus honey. J Sci Fd Agric. 1993;61(1):121-3.

[12]. French VM, Cooper RA, Molan PC. The antibacterial activity of honey against coagulase-negative staphylococci. J Antimicrob Chemother. 2005 Jul;56(1):228-31. PubMed PMID: 15941774.

[13]. Ghashm AA, Othman NH, Khattak MN, Ismail NM, Saini R. Antiproliferative effect of Tualang honey on oral squamous cell carcinoma and osteosarcoma cell lines. BMC Complement Altern Med. 2010 Sep 14;10:49. doi: 10.1186/1472-6882-10-49. PubMed PMID: 20840769.

[14]. Gheldof N, Engeseth NJ. Antioxidant capacity of honeys from various floral sources based on the determination of oxygen radical absorbance capacity and inhibition of in vitro lipoprotein oxidation in human serum samples. J Agric Food Chem. 2002 May 8;50(10):3050-5. PubMed PMID: 11982440.

[15]. Kajiwara S, Gandhi H, Ustunol Z. Effect of honey on the growth of and acid production by human intestinal Bifidobacterium spp.: an in vitro comparison with commercial oligosaccharides and inulin. J Food Prot. 2002 Jan;65(1):214-8. PubMed PMID: 11808799.
[16]. Miguel MG, Antunes MD, Faleiro ML. Honey as a complementary medicine. Integr Med Insights. 2017 Apr 24;12:1178633717702869. doi: 10.1177/1178633717702869. PubMed PMID: 28469409.

[17]. Mohan A, Quek SY, Gutierrez-Maddox N, Gao Y, Shu Q. Effect of honey in improving the gut microbial balance. Fd Quality Safety. 2017 May 1;1(2):107-15.

[18]. Oddo LP, Piazza MG, Sabatini AG, Accorti M. Characterization of unifloral honeys. Apidologie. 1995;26(6):453-65.

[19]. Pérez-Arquillué C, Conchello P, Ariño A, Juan T, Herrera A. Physicochemical attributes and pollen spectrum of some unifloral Spanish honeys. Fd Chem. 1995 Jan 1;54(2):167-72.

[20]. Perina NP, Granato D, Hirota C, Cruz AG, Bogsan CS, Oliveira MN. Effect of vegetal-oil emulsion and passion fruit peel-powder on sensory acceptance of functional yogurt. Fd Res Int. 2015 Apr 1;70:134-41.

[21]. Rashid A, Thakur ES. Studies on quality parameters of set yoghurt prepared by the addition of honey. Int J Scientific Res Pub. 2012;2(9):1-0.

[22]. Sarkar S. Potentiality of probiotic yoghurt as a functional food-a review. Nutr Fd Sci. 2018 Sep 8.

[23]. Sarkar S. Enhanced Functionality Of Fruit Yoghurt. Int J Food Sci Nutr Diet. 2018;7(1e):1.

[24]. Sheehan VM, Ross P, Fitzgerald GF. Assessing the acid tolerance and the technological robustness of probiotic cultures for fortification in fruit juices. Inno Fd Sci Emerg Technologies. 2007 Jun 1;8(2):279-84.

[25]. Swallow KW, Low NH. Analysis and quantitation of the carbohydrates in honey using high-performance liquid chromatography. J Agric Fd Chem. 1990 Sep;38(9):1828-32.

[26]. Ustunol Z, Gandhi H. Growth and viability of commercial Bifidobacterium spp. in honey-sweetened skim milk. J Food Prot. 2001 Nov;64(11):1775-9. PubMed PMID: 11726158. 